\title{
INTERAKSI POLITIK DAN HUKUM DALAM PEMBENTUKAN LEGISLASI DAERAH (STUDI TERHADAP PROSES PENYUSUNAN PERATURAN DAERAH DI DEWAN PERWAKILAN RAKYAT DAERAH KOTA SURAKARTA)
}

\author{
Isharyanto, Adriana Grahani Firdausy Fakultas Hukum \\ Universitas Sebelas Maret Surakarta Email : \\ masis_uns@yahoo.com; grahani_81@yahoo.com
}

\begin{abstract}
This study aims to analyze and review law and politic interactions in drafting legislation in the area of the Regional Representatives Council of the City of Surakarta. Will be tested conceptualization commonly accepted that there is an interaction between law and politics in the process of legislation, so that the perspective used is a law which is not simply a normative sense, but influenced by the layout of the resultant interaction with other factors. This study is an empirical legal research. How to obtain the data held with the literature study and interviews. As an object of observation, then conducted the study and analysis of regional regulation Surakarta generated for the period 2005-2010 and this research, performed sorting into 3 clumps of Local regulations relating to the collection and Licensing, Government Activities, and Social Community. Based on research results that local regulation in the clump of government activity have a similar pattern of interaction of political and legal issues than local regulation and licensing in the family collection. The similarity is apparent in At a working meeting with the regional political system this interaction is actually happening. In such interactions will occur bargaining process and argument in order to obtain a common perception among the Special committee with the regional to the substance of the draft regulation. Meanwhile, local regulation in clumps social activity that particularly made an object of this study showed variation facts. Whenever it is deemed to include the substance of the rules of public interest and can be used as a reason for the interests of certain social groups such as the Local regulation of Education, will take some time for discussion indicates attraction between politics and law in the process of discussion. Then, in the case of the Regional Equality Regulations disabilities, in addition to the widely recognized and important problem, but because it targets only certain elite discussion, in this case the regional, then it does not show interactions that complicate the process of discussion.
\end{abstract}

Keywords: law and politic, legislation, local interest.

\begin{abstract}
Abstrak
Penelitian ini bertujuan untuk menganalisis dan mengkaji interaksi politik dan hukum dalam penyusunan legislasi daerah di Dewan Perwakilan Rakyat Daerah Kota Surakarta. Akan diuji konseptualisasi yang lazim diterima bahwa ada interaksi antara hukum dan politik dalam proses legislasi, sehingga perspektif yang digunakan adalah hukum tidaklah sekedar pengertian normatif, akan tetapi merupakan resultan yang dipengaruhi oleh tata interaksi dengan faktor-faktor lain. Penelitian ini merupakan penelitian hukum empiris yang bersifat deskriptif. Cara memperoleh data dilaksanakan dengan studi pustaka dan wawancara. Sebagai obyek pengamatan, maka dilakukan kajian dan analisis terhadap Peraturan Daerah Kota Surakarta yang dihasilkan kurun 2005-2010 dan untuk riset ini, dilakukan pemilahan ke dalam 3 rumpun yaitu Peraturan Daerah yang terkait dengan Pemungutan dan Perizinan, Aktivitas Pemerintahan, dan Sosial Kemasyarakatan. Berdasarkan hasil penelitian bahwa Peraturan Daerah dalam rumpun aktivitas pemerintahan mempunyai pola yang sama terhadap masalah interaksi politik dan hukumnya dibandingkan Peraturan Daerah dalam rumpun pemungutan dan perizinan. Kesamaan itu nampak dalam Pada saat rapat kerja dengan Perangkat Daerah inilah interaksi sistem politik yang sebenarnya terjadi. Dalam interaksi tersebut akan terjadi proses tawar-menawar dan adu argumentasi dalam rangka memperoleh kesamaan persepsi antara Panitia Khusus dengan Perangkat Daerah terhadap substansi Rancangan Peraturan Daerah. Sementara itu, Peraturan Daerah dalam rumpun aktivitas sosial kemasyarakatan yang khususnya dijadikan obyek studi ini menunjukkan variasi fakta. Bilamana substansi aturan itu dianggap mencakup kepentingan masyarakat luas dan dapat dijadikan
\end{abstract}


alasan untuk memperjuangkan kepentingan kelompok-kelompok masyarakat tertentu maka seperti Peraturan Daerah Pendidikan, akan memakan waktu untuk pembahasan yang menunjukkan adanya tarik menarik antara politik dan hukum dalam proses pembahasannya. Kemudian, dalam kasus Peraturan Daerah Kesetaraan Difabel, di samping masalahnya diakui luas dan penting, namun karena sasaran pembahasannya hanya elit tertentu, dalam hal ini Perangkat Daerah, maka tidak menunjukkan interaksi yang mempersulit proses pembahasannya.

Kata Kunci: hukum dan politik, legislasi, kepentingan lokal.

\section{A. Pendahuluan}

Pasal 18 ayat (2) Undang-undang Dasar Negara Republik Indonesia Tahun 1945 menyebutkan Pemerintahan daerah provinsi, daerah kabupaten, dan kota mengatur dan mengurus sendiri urusan pemerintahan menurut asas otonomi dan tugas pembantuan. Sedangkan konsideran menimbang Undang-undang Nomor 32 Tahun 2004 huruf b antara lain menyebutkan : “..... memberikan kewenangan yang seluasluasnya kepada daerah disertai dengan pemberian hak dan kewajiban menyelenggarakan otonomi daerah dalam kesatuan sistem penyelenggaraan pemerintahan negara."

Kewenangan/urusan pemerintahan yang diberikan dalam otonomi daerah pada dasarnya adalah terhadap seluruh kewenangan pemerintahan, kecuali terhadap hal-hal yang secara tegas dinyatakan dalam Undang-undang Nomor 32 Tahun 2004; yaitu politik luar negeri, pertahanan keamanan, yustisi, moneter dan fiskal nasional dan agama. Pembagian Urusan Pemerintahan ini diatur dalam Pasal 10 Undangundang Nomor 32 Tahun 2004. Pasal 10 ayat (1) UU Nomor 32 Tahun 2004 menyebutkan :

"pemerintahan daerah menyelenggarakan urusan pemerintahan yang menjadi kewenangannya, kecuali urusan urusan pemerintahan yang oleh Undang-Undang ini ditentukan menjadi urusan pemerintah".

Sedangkan Pasal 10 ayat (2) menyatakan :

"Dalam menyelenggarakan urusan pemerintahan yang menjadi kewenangan daerah sebagaimana dimaksud ayat (1), pemerintahan daerah menjalankan otonomi seluas-luasnya untuk mengatur dan mengurus sendiri urusan pemerintahan berdasarkan asas otonomi dan tugas pembantuan".

Dengan adanya otonomi daerah yang memberikan kewenangan luas kepada daerah untuk mengatur dan mengurus rumah tangganya sendiri, seyogianya Pemerintahan Daerah dapat menetapkan produk hukum daerah sesuai dengan kebutuhan dan kepentingan daerahnya tanpa harus terlalu banyak tergantung dan selalu menunggu petunjuk dari Pemerintah Pusat. Ketegasan mengenai hal ini juga telah ditentukan dalam Pasal 18 ayat (6) Undang-Undang Dasar Negara Republik Indonesia Tahun 1945 yang menyebutkan :

"pemerintah daerah berhak menetapkan peraturan daerah dan peraturan-peraturan lain untuk melaksanakan otonomi dan tugas pembantuan".

Berdasarkan pernyataan Pasal 18 ayat (6) Undang-undang Dasar Negara Republik Indonesia Tahun 1945 tersebut, tersimpul makna bahwa Pemerintahan Daerah dapat membentuk peraturan daerah dan peraturan-peraturan lainnya sesuai dengan aspirasi masyarakat dan kebutuhan nyata daerahnya sepanjang tidak bertentangan dengan ketentuan yang berlaku. Disinilah terlihat adanya kewenangan luas dan nyata bagi daerah untuk melahirkan produk hukum daerah, guna menyelenggarakan urusan pemerintahannya berdasarkan otonomi yang dimiliki. Dalam implementasinya ternyata hak tersebut tidak dapat dilaksanakan sebagaimana mestinya karena adanya permasalahan-permasalahan dalam pembentukan produk hukum daerah, baik dari segi aturan-aturan yang menjadi acuan/dasarnya maupun dari lembaga pembentuknya sendiri.

Salah satu persoalan dalam pembentukan Peraturan Daerah berangkat dari asumsi dasar bahwa proses pembentukan hukum (legislasi) dalam melahirkan hukum positif (in abstracto) akan sesuai dan selalu dipengaruhi oleh konfigurasi politik tertentu yang berinteraksi dalam proses tersebut. Adanya interaksi politik ke dalam legislasi ini telah diingatkan oleh gerakan critical Legal Studies (CLS) bahwa dalam proses legislasi nyaris terjadi tolak tarik, negotiable, subjective and policy dependent as politics antarsubjek yang terlibat di dalamnya. Proses legislasi untuk menjadikan hukum positif (in abstracto) nyatanya selalu merupakan hasil dari proses yang sarat dengan 
berbagai muatan, nilai, dan kepentingan para aktor, yang di dalamnya, baik pada saat dalam proses pembentukan hingga pemberlakuannya, niscaya mengandung pemihakan-pemihakan (F.X. Adji Samekto, 2003: 68). Hal ini disebabkan, seperti pernyataan M. Solly Lubis, politik itu adalah penentuan kebijakan umum mengenai pengelolaan dan pengendalian masyarakat (public policy making) (M. Solly Lubis, 1989: 64). Asumsi tersebut untuk sebagian dapat dikatakan benar, sebab proses legislasi berada di lembaga legislatif yang cenderung lebih beraspek politik (Satjipto Rahardjo, 1980: 82-92). Akan tetapi asumsi tersebut belum lengkap, karena dalam legislasi tidak semata-mata hanya persoalan intervensi dan interaksi politik ke dalam proses tersebut. Nyata dalam teori maupun praktik akan tampak bahwa proses legislasi juga tidak lepas dari hukum (dalam arti hukum perundang-undangan/peraturan perundang-undangan) (Moh. Mahfud M.D., 1998: 24-25).

Satjipto Rahardjo (2003: 15) mengatakan bahwa inti legislasi terdiri atas dua golongan besar, yaitu tahap sosiologis (sosio-politis) dan tahap yuridis. Dalam tahap sosiologis berlangsung proses-proses untuk mematangkan suatu gagasan dan/atau masalah yang selanjutnya akan dibawa ke dalam agenda yuridis. Apabila gagasan itu berhasil dilanjutkan, bisa jadi bentuk dan isinya mengalami perubahan, yakni makin dipertajam (articulated) dibanding pada saat ia muncul. Pada titik ini, ia akan dilanjutkan ke dalam tahap yuridis yang merupakan pekerjaan yang benarbenar menyangkut perumusan atau pengkaidahan suatu peraturan hukum. Tahap ini melibatkan kegiatan intelektual yang murni bersifat yuridis yang niscaya ditangani oleh tenaga-tenaga yang khusus berpendidikan hukum.

Ketentuan dalam UU No. 32 Tahun 2004 telah menggariskan bahwa pembentukan Peraturan Daerah adalah dalam kerangka penyelenggaraan otonomi daerah provinsi/kabupaten/kota dan tugas pembantuan (Pasal 136 ayat (2) dibuat untuk mengurus urusan pemerintahan dan kepentingan masyarakat setempat menurut prakarsa sendiri berdasarkan aspirasi masyarakat dalam sistem Negara Kesatuan Republik Indonesia" (Pasal 1 angka 6). Dengan prinsip "berdasarkan aspirasi masyarakat" tersebut, maka UU No. 32 Tahun 2004 telah memberikan jalan bagi interaksi politik demokratis dalam legislasi Peraturan Daerah. Dalam Penjelasan UU tersebut juga ditegaskan bahwa “... penyelenggaraan otonomi daerah harus selalu berorientasi pada peningkatan kesejahteraan masyarakat dengan selalu memperhatikan kepentingan dan aspirasi yang tumbuh dalam masyarakat" Berdasarkan pemahaman yang demikian itu, maka pembentukan Perda yang ideal haruslah selalu berorientasi kepada nilai, kepentingan, kebutuhan, preferensi, dan aspirasi yang tumbuh dalam masyarakat. Idealitas orientasi yang demikian ini hanya dapat diwujudkan manakala masyarakat luas dilibatkan secara substantif dalam legislasi Perda. Ini berarti, sistem politik demokratis merupakan prasyarat yang niscaya (conditio sine qua non) dalam mewujudkan legislasi Perda yang ideal tersebut. Tidak hanya berdasarkan hal-hal tersebut di atas, UU No. 32 Tahun 2004 dan UU No. 10 Tahun 2004 tentang Pembentukan Peraturan Perundang-undangan telah menentukan bahwa agar dari suatu proses legislasi dapat dilahirkan Peraturan Daerah yang ideal, maka pembentukan Peraturan Daerah harus berdasarkan asas-asas pembentukan peraturan perundang-undang yang baik.

Paparan di atas menunjukkan bahwa Peraturan Daerah sebagai salah satu jenis peraturan perundang-undangan yang paling banyak diterbitkan di Indonesia memiliki banyak dimensi. Tidak hanya berdimensi hukum, tetapi juga berdimensi perekonomian, berdimensi sosial dan berdimensi politik. Munculnya Peraturan Daerah bermasalah pada dasarnya juga bisa ditelaah dari empat dimensi tersebut. Peraturan Daerah bermasalah muncul karena law makers tidak mampu menangkap aspirasi dunia usaha dan tidak mencerminkan aspirasi masyarakat setempat - tegasnya tidak demokratis -, bertentangan dengan hukum yang lebih tinggi, dan sarat dengan pertimbangan kepentingan politik yang bisa jadi tidak selaras dengan aspirasi maupun kepentingan publik. Oleh karenanya menjadi sangat urgen untuk dilakukan studi lebih lanjut lewat suatu penelitian untuk melihat interaksi politik dalam proses pembentukan Peraturan Daerah.

Berdasarkan uraian di atas, maka telah memadai kiranya untuk menjelaskan tentang latar belakang pemikiran peneliti serta ke arah mana studi ini akan dilakukan dalam menggarap tema yang sekaligus merupakan judul studi, yakni "Interaksi Politik dan Hukum dalam Pembentukan Legislasi Daerah (Studi terhadap Proses Penyusunan Peraturan Daerah di Dewan Perwakilan Rakyat Daerah Kota Surakarta)." 


\section{B. Metode Penelitian}

Spesifikasi penelitian dalam studi ini adalah penelitian deskriptif analitis. Menurut Kamus Bahasa Indonesia, "analitis" (analisistis) artinya adalah bersifat analisis. Sedangkan arti analisis di antaranya adalah "proses pemecahan masalah yang dimulai dengan dugaan akan kebenarannya" (Sulchan Yashin (Ed.), 1997: 34). Penelitian deskriptif adalah suatu penelitian yang bersifat pemaparan dalam rangka menggambarkan selengkap mungkin tentang suatu keadaan yang berlaku di tempat tertentu, atau suatu gejala yang ada, atau juga peristiwa tertentu yang terjadi dalam masyarakat dalam konteks penelitian (Abdulkadir Muhammad, 2004: 10). Jenis data yang digunakan dalam penelitian ini ada 2 (dua) macam, yaitu data sekunder dan data primer. Penggunaan data demikian dikarenakan penelitian ini menggunakan pendekatan sosio-legal, yang diawali dengan melakukan telaah terhadap aspek normatif tentang proses pembentukan Peraturan Daerah yang kemudian dilanjutkan dengan mengkajinya dalam ranah sosio-empirik. Data sekunder dimaksudkan untuk memperoleh pemahaman tentang prosedur hukum pembentukan Peraturan Daerah, yakni berupa inventarisasi peraturan perundang-undangan di bidang pembentukan Peraturan Daerah beserta konsep-konsep hukum dan doktrin-doktrin hukumnya. Dengan demikian sumber data skunder ini berasal dari berbagai bahan hukum, yang terdiri atas bahan hukum primer, bahan hukum skunder, dan bahan hukum tertier (Soerjono Soekanto, 1985: 52).

Metode pengumpulan data yang digunakan dalam penelitian ini terdiri atas 2 (dua) cara, yaitu: (1) studi pustaka, dan (2) wawancara. Studi pustaka digunakan dalam rangka pengumpulan data sekunder. Pengumpulan data dengan menggunakan studi pustaka ini ditempuh dengan cara mengumpulkan, membaca, menelaah, mengkaji, serta mengkritisi ketentuan peraturan perundang-undangan terkait dengan pembentukan Peraturan Daerah, memorie van toelichting/risalah persidangan, doktrin dan pendapat para pakar, jurnal, serta hasil-hasil penelitian sejenis yang pernah dilakukan oleh peneliti lain sebelumnya yang ada kaitannya dengan tema penelitian ini.

Dalam rangka keperluan ini, maka Peraturan Daerah sebagai obyek pengamatan adalah Peraturan Daerah yang dibentuk dalam kurun waktu 2005-2010 yang mencapai 49 Peraturan Daerah. Dari jumlah tersebut, untuk kepentingan pembahasan rumusan masalah dipilah ke dalam 3 (tiga) rumpun Peraturan Daerah yang masing-masing meliputi: (i) Rumpun Peraturan Daerah dalam Pemungutan dan Perizinan, yaitu Peraturan Daerah yang berkaitan dengan Pajak Daerah, Retribusi Daerah, serta izin usaha/ penyelenggaraan kegiatan tertentu; (ii) Rumpun Peraturan Daerah dalam Aktivitas Pemerintahan, yaitu Peraturan Daerah yang berkaitan dengan pengorganisasian dan tata laksana pemerintahan daerah, akan tetapi tidak mencakup Anggaran Pendapatan dan Belanja Daerah serta pendirian badan usaha daerah; dan (iii) Rumpun Peraturan Daerah dalam Sosial Kemasyarakatan yaitu Peraturan Daerah yang berhubungan dengan penyelesaian dan pengaturan masalah-masalah sosial kemasyarakatan, yang dalam hal ini dibatasi pada masalah Pendidikan dan Kesetaraan Difabel.

Analisis dilakukan setelah membaca keseluruhan Peraturan Daerah akan tetapi tidak memberikan komentar terhadap substansi dan aspek teknis penyusunan aturan, melainkan difokuskan kepada pengalaman informan dalam pembahasan Peraturan Daerah yang bersangkutan guna memperoleh komentar dan informasi sebagai bahan dan data penelitian menyangkut interaksi politik dan hukum dalam pembentukan legislasi di Dewan Perwakilan Rakyat Daerah Kota Surakarta. Mengingat informasi itu bisa jadi merupakan kesan atau pendapat pribadi, maka untuk obyektifitas bahan dan data penelitian, dipilah dan diedit dalam format tulisan, dan diseleksi peneliti sehingga benarbenar informasi yang relevan dengan keperluan penelitian saja yang digunakan. Kemudian, pilihan informasi juga diletakkan kepada yang mempunyai relevansi antara informasi yang satu dengan yang lain sehingga diperoleh deskripsi yang utuh dari daftar pertanyaan yang diajukan oleh peneliti.

\section{Hasil Penelitian dan Pembahasan}

\section{Negara Hukum dan Otonomi daerah}

Sebagai bangsa merdeka dan berdaulat, perencanaan dan penetapan konsep mengenai sistem pengelolaan kehidupan berbangsa diserahkan sepenuhnya kepada sebuah bangsa sesuai dengan cita-cita untuk kehidupan kebangsaan yang bebas, merdeka, bersatu, berdaulat, adil dan makmur (M. Solly Lubis, 1989: 2). Secara teoritis bahwa semua bangsa menuangkan pokok-pokok pandangan, pendirian, prinsip konseptual, mengenai pengelolaan kehidupannya di dalam konstitusi, baik tertulis (written

Interaksi Politik dan Hukum dalam Pembentukan ... 37 
constitution) maupun tidak tertulis (unwritten constitution). Undang-Undang Dasar sebagai konstitusi tertulis umumnya mengemukakan latar belakang hasrat bernegara, landasan filosofi kenegaraan, tujuan Negara, struktur organisasi dan mekanisme pemerintahan Negara yang diinginkan oleh bangsa yang mendirikan dan mempertahankan Negara itu (H.R. Ridwan, 2004: 4). Tipe negara hukum ini sering juga disebut negara hukum dalam arti yang luas atau disebut pula Negara Hukum Modern. Negara dalam pengertian ini bukan saja menjaga keamanan sematamata tetapi secara aktif turut serta dalam urusan kemasyarakatan demi kesejahteraan rakyat. Oleh sebab itu pengertian negara hukum dalam arti materiel atau luas sangat erat hubungannya dengan pengertian Negara Kesejahteraan atau "welfare state" (H. R. Ridwan, 2004: 4).

Sejalan dengan hal tersebut pemerintah mengeluarkan kebijakan melalui Perundangundangan tentang otonomi daerah yaitu UU No. 32 Tahun 2004 tentang Pemerintahan Daerah dan kemudian dilengkapi dengan Undang-undang Nomor 33 Tahun 2004 tentang perimbangan Keuangan Pusat dan Daerah, meletakkan perubahan mendasar dengan melaksanakan kebijaksanaan desentralisasi. Pengertian pemerintahan daerah menurut UU No. 32 Tahun 2004 ialah penyelenggaraan urusan pemerintahan oleh pemerintah daerah dan DPRD, menurut asas otonomi dan tugas pembantuan dengan prinsip otonomi seluasluasnya dalam sistem dan prinsip Negara Kesatuan Republik Indonesia, sebagaimana dimaksud dalam UUD 1945. Asas otonomi daerah yang artinya ialah hak, wewenang dan kewajiban daerah otonom untuk mengatur dan mengurus sendiri urusan pemerintahan dan kepentingan masyarakat setempat sesuai peraturan perundang-undangan. Dengan daerah otonom dimaksudkan agar daerah dapat berkembang sesuai dengan kemampuannya sendiri dan tidak bergantung pada Pemerintah Pusat, sehingga daerah harus mampu mengatur pendapatan dan pengeluarannya sendiri. Sistem desentralisasi ini Pemerintah Daerah diberi kewenangan untuk membuat kebijakan dan mengatur rumah tangganya sendiri. Selain itu tujuan kebijakan desentralisasi yakni dalam rangka efisiensi alokasi arus barang publik ke daerah, serta untuk mendekatkan pelayanan kepada masyarakat lokal guna mendorong demokratisasi, mengakomodasi aspirasi dan partisipasi masyarakat daerah.

\section{Interaksi Politik dan Hukum}

Ada pandangan bahwa hukum itu merupakan produk politik sebab kelahirannya diproses melalui interaksi politik. Jika dikaji dalam perspektif yang lebih luas, sejatinya badan/satuan politik itu tidak lain adalah produk dari suatu struktur sosial. Dalam pemahaman yang lebih luas, Daniel S. Lev membuat proposisi bahwa di samping hukum itu selalu merupakan formasi politik, tetapi juga merupakan suatu formasi sosial dan ekonomi (Daniel S. Lev, 2004: 144).

Berdasar sekalian paparan tersebut, studi ini mengkonsepsikan interaksi politik dalam proses pembentukan hukum sebagai proses saling pengaruh-mempengaruhi serta saling meminta dan memberi (take and give) dan saling intervensi antara pihak-pihak yang terlibat dalam suatu kekuasaan legislasi (yakni antara legislatif dan eksekutif) dalam proses pembentukan hukum. Dengan adanya interaksi tersebut, maka asumsi yang hendak dibangun adalah "hukum merupakan produk politik."

3. Interaksi Politik dan Hukum dalam Pembahasan Rancangan Peraturan daerah

Selama kurun waktu 2005-2010, di Kota Surakarta telah dapat disusun sebanyak 49 (empatpuluh sembilan) Peraturan Daerah. Dari keseluruhan jumlah tersebut, dikaitkan dengan data penelitian ini, dapat dikualifikasikan sebagai berikut. pertama, Peraturan Daerah Rumpun Pemugutan dan Perizinan, sebanyak 8 (delapan) Peraturan Daerah. Kedua, Peraturan Daerah Rumpun Aktivitas Pemerintahan sebanyak 6 (enam) Peraturan Daerah.Ketiga, Peraturan Daerah Rumpun Sosial Kemasyarakatan sebanyak 6 (enam) Peraturan Daerah. Secara relatif, Peraturan Daerah yang dibentuk pada kurun waktu 2005-2010 dalam rumpun pemungutan dan perizinan memiliki jumlah yang lebih banyak dibandingkan dengan total peraturan yang dibentuk yaitu sebanyak hampir 50\%, kemudian disusul dengan aktivitas pemerintahan sebanyak hampir $41 \%$, dan sosial kemasyarakatan sebanyak hampir $8 \%$. 
Berdasarkan data yang diperoleh dari informan yang mengikuti pembahasan di Dewan, proses pembahasan itu dilakukan oleh Panitia Khusus yang dibentuk oleh Dewan. Dalam melakukan pembahasan, bentuk atau rangkaian tindakannya tidak sekedar pertemuan saja tetapi juga:

a. Panitia Khusus melakukan rapat kerja dengan Perangkat Daerah yang terkait dengan materi yang dibahas dalam Rancangan Peraturan Daerah;

b. Panitia Khusus melakukan dengar pendapat (hearing) dengan pemangku kepentingan (stakeholders) yang "terkena" pengaturan Peraturan Daerah;

c. Panitia Khusus melakukan peninjauan lapangan ke lokasi tertentu untuk memperoleh masukan dari masyarakat;

d. Panitia Khusus melakukan studi banding ke daerah lain untuk memperoleh informasi yang relevan dengan materi Rancangan Peraturan Daerah;

e. Panitia Khusus meminta kalangan perguruan tinggi untuk melakukan telaah terhadap materi Rancangan Peraturan Daerah;

f. Panitia Khusus mengadakan konsultasi kepada pejabat di provinsi maupun di tingkat Pusat terkait dengan pengawasan dan pembinaan Peraturan Daerah;

g. Panitia Khusus mengadakan uji publik terhadap Rancangan Peraturan Daerah; dan

h. Panitia Khusus mengadakan rapat internal yang hanya dihadiri oleh anggotaanggota Panitia Khusus.

Dari keterangan yang diperoleh dalam wawancara, dapat dianalisis bahwa interaksi antara Panitia Khusus dengan leading sector dalam pembahasan Rancangan Peraturan Dearh di lokasi penelitian tampak berjalan dengan tenang. Tidak ada tekanan yang keras dari Panitia Khusus terhadap Rancangan Peraturan Daerah yang diajukan oleh Pemerintah Kota, kecuali hanya ingin memperoleh pemahaman tentang maksud dan tujuan pengusulan Rancangan Peraturan Daerah yang bersangkutan, serta kelayakannya jika nanti disetujui menjadi Peraturan Daerah. Bahkan dalam pembahasan Rancangan Peraturan Daerah tentang Kedudukan Protokoler dan Keuangan DPRD yang dilakukan oleh Panitia Khusus dan Perangkat Daerah berjalan sangat singkat, karena hal itu hanya menyangkut hak-hak normatif keuangan anggota DPRD yang telah ada rujukan yuridisnya.

Pembahasan antara Panitia Khusus dengan Perangkat Daerah yang pada umumnya relatif tenang tersebut dikarenakan Rancangan Peraturan Daerah yang dibahas tidak memiliki implikasi baik langsung maupun tidak langsung terhadap kepentingan Panitia Khusus. Oleh karenanya dalam pembahasan Rancangan Peraturan Daerah tidak ada "janjijanji khusus" yang diberikan pihak pengusul agar Rancangan Peraturan Daerah tersebut segera disetujui.

Rapat khusus/intern dilaksanakan dalam rangka membuat rencana kerja, inventarisasi masalah, menyaring, dan merumuskan hasil masukan dari masyarakat yang diperoleh lewat public hearing dan kunjungan lapangan, merumuskan hasil pembicaraan dalam interaksi sistem politiknya dengan eksekutif yang dilakukan pada saat rapat kerja, membetulkan rumusan kalimat dalam pasal, merubah dan memperbaiki substansi rumusan pasal, menyusun kesimpulan dan rekomendasi, serta membuat laporan hasil kerja Pansus yang akan disampaikan dalam Rapat Paripurna terakhir. Kesimpulan dan rekomendasi Panitia Khusus menjadi rujukan Fraksi-fraksi dalam menyusun Pandangan Akhir serta sebagai rekomendasi kepada Dewan untuk menerima atau menolak Rancangan Peraturan Daerah menjadi Peraturan Daerah.

Informan dari kalangan Dewan yang diwawancarai memberikan jawaban bahwa seluruh Rancangan Peraturan Daerah yang tengah dibahas pasti dipublikasikan/ disosialisasikan dalam rangka mencari masukan dari masyarakat. Namun pendapat demikian itu akan berbeda halnya jika menelusuri jadwal acara Panitia Khusus maupun Laporan Hasil Kerja Panitia Khusus. Dari penelahaan tersebut ternyata public hearing Panitia Khusus untuk memperoleh masukan dari publik terkait (stakeholders) kadang diagendakan, tapi juga kadang tidak dilaksanakan.

Hasil penelitian menunjukkan bahwa Peraturan Daerah dalam rumpun aktivitas pemerintahan mempunyai pola yang sama terhadap masalah interaksi politik dan 
hukumnya dibandingkan Peraturan Daerah dalam rumpun pemungutan dan perizinan. Kesamaan itu nampak dalam Pada saat rapat kerja dengan Perangkat Daerah inilah interaksi sistem politik yang sebenarnya terjadi. Dalam interaksi tersebut akan terjadi proses tawar-menawar dan adu argumentasi dalam rangka memperoleh kesamaan persepsi antara Panitia Khusus dengan Perangkat Daerah terhadap substansi Rancangan Peraturan Daerah. Dengan tawar menawar, saling adu argumentasi, dan saling pengaruh-mempengaruhi tersebut akan dapat dicapai kesepakatan-kesepakatan terkait apakah Rancangan Peraturan Daerah layak dilanjutkan, tidak dilanjutkan, atau ditunda pembahasannya. Jika tidak layak dilanjutkan atau ditunda pembahasannya, maka di akhir pembicaraan direkomendasikan untuk ditolak dan/atau ditunda. Jika layak dilanjutkan, maka akan diteruskan pembahasan dengan melakukan kesepakatan untuk mengadakan perbaikan/penyempurnaan Rancangan Peraturan Daerah, baik menyangkut sisi sistematikanya, rumusan tata naskahnya, maupun menyangkut substansi-materinya.

Peraturan Daerah dalam rumpun aktivitas sosial kemasyarakatan yang khususnya dijadikan obyek studi ini menunjukkan variasi fakta. Bilamana substansi aturan itu dianggap mencakup kepentingan masyarakat luas dan dapat dijadikan alasan untuk memperjuangkan kepentingan kelompokkelompok masyarakat tertentu maka seperti Peraturan Daerah Pendidikan, akan memakan waktu untuk pembahasan yang menunjukkan adanya tarik menarik antara politik dan hukum dalam proses pembahasannya. Kemudian, dalam kasus Peraturan Daerah Kesetaraan Difabel, di samping masalahnya diakui luas dan penting, namun karena sasaran pembahasannya hanya elit tertentu, dalam hal ini Perangkat Daerah, maka tidak menunjukkan interaksi yang mempersulit proses pembahasannya.

Hanya saja dalam membaca interaksi politik dan hukum itu, dalam rumpun Peraturan Daerah ini ada kesamaan dengan rumpunrumpun sebelumnya. Kesamaan itu nampak dalam Pada saat rapat kerja dengan Perangkat Daerah inilah interaksi sistem politik yang sebenarnya terjadi. Dalam interaksi tersebut akan terjadi proses tawar-menawar dan adu argumentasi dalam rangka memperoleh kesamaan persepsi antara Panitia Khusus dengan Perangkat Daerah terhadap substansi Rancangan Peraturan Daerah. Dengan tawar menawar, saling adu argumentasi, dan saling pengaruh-mempengaruhi tersebut akan dapat dicapai kesepakatan-kesepakatan terkait apakah Rancangan Peraturan Daerah layak dilanjutkan, tidak dilanjutkan, atau ditunda pembahasannya. Jika tidak layak dilanjutkan atau ditunda pembahasannya, maka di akhir pembicaraan direkomendasikan untuk ditolak dan/atau ditunda. Jika layak dilanjutkan, maka akan diteruskan pembahasan dengan melakukan kesepakatan untuk mengadakan perbaikan/penyempurnaan Rancangan Peraturan Daerah, baik menyangkut sisi sistematikanya, rumusan tata naskahnya, maupun menyangkut substansi-materinya.

4. Kerangka Ideal Proses Pembentukan Peraturan daerah dalam Perspektif Interaksi Hukum dan Politik di Kota Surakarta Ke depan

Penelitian ini telah menguraikan dan membuktikan bahwa dalam interaksi politik dan hukum dalam pembentukan Peraturan Daerah tampak cenderung elitis. Berangkat dari konfigurasi politik demokrasi yang cenderung elitis tersebut ketika berinteraksi dalam legislasi - yang dalam studi ini adalah legislasi Perda - tampaknya juga cenderung memperlihatkan watak yang elitis. Demokrasi perwakilan yang demikian itu, seperti yang dikatakan oleh Franz Magnis-Suseno, memiliki dua kelemahan yaitu: pertama, rakyat tidak langsung dapat membuat undangundang, melainkan melalui wakil-wakil yang mereka pilih. Keputusan-keputusan yang paling penting dalam kenyataannya diambil oleh beberapa orang saja. Maka dalam demokrasi perwakilan akan muncul unsur elitisme. Elitisme ini ditandai dengan terbatasnya implementasi asas ketebukaan dan akhirnya terbatas juga partisipasi masyarakat dalam proses pengambilan keputusan. Kedua, demokrasi perwakilan dapat menjadi totaliter jika mayoritas rakyat memutlakkan kehendaknya, dan tidak menutup kemungkinan menjadi oligarkis jika minoritas memutlakkan kehendaknya terhadap mayoritas (Franz-Magnis Suseno, 1999: 290-294).

Untuk menghindarkan demokrasi menjadi elitis seperti itu, kemudian muncul pemikiran 
agar demokrasi "diperbaiki dan dikembalikan" pada prinsip dasarnya. Gagasan yang muncul dari teori demokrasi partisipatif barang tentu menjadi jawaban terhadap elitisme demokrasi. Bahkan munculnya gagasan teori demokrasi deliberatif semakin memperkuat gagasan untuk meletakkan demokrasi menjadi partisipatif.

Dengan demikian tampak sudah bahwa agar produk hukum daerah tidak berparadigma elitisme, maka kehendak elite harus dipertemukan dengan kehendak umum rakyat. Berdasarkan hal ini, maka idealnya dalam sekalian tahapan legislasi Peraturan Daerah niscaya harus dapat mempertemukan antara kehendak, kepentingan, dan kebutuhan elite dengan kehendak, kepentingan, dan kebutuhan rakyat. Inilah yang semakin memperkokoh argumentasi perlunya untuk membangun suatu konsep ideal legislasi Peraturan Daerah masa depan yang berparadigmakan demokrasi elitis-populis. Konsep yang ideal tentang legislasi Peraturan Daerah yang mencerminkan demokrasi elitispopulis tersebut dapat diketengahkan sebagai berikut.

pertama, elite daerah, baik yang berada di lembaga legislatif maupun di lembaga eksekutif, pada setiap tahapan legislasi Peraturan Daerah yang dimulai dari proses perencanaan, pembahasan, hingga pengambilan keputusan atas suatu Rancangan Peraturan Daerah niscaya selalu melibatkan warga masyarakat lokal. Pelibatan masyarakat dalam setiap tahapan legislasi Perda tidak sekedar dalam tataran formalprosedural saja, namun dalam maknanya yang lebih substantif. Maksudnya, pelibatan warga masyarakat lokal tidak hanya berlangsung dalam satu acara yang bersifat seremonial saja untuk menunjukkan bahwa elite daerah telah bekerja secara demokratis, namun pelibatan tersebut harus dilakukan seintensif dan seefektif mungkin. Pada titik ini, pelibatan warga lokal tidak sekedar diminta untuk memberi masukan-masukan saja dan setelah itu dibiarkan dan tidak disentuh oleh elite, namun warga masyarakat setempat diberi peluang berdasarkan hukum untuk secara terus menerus melakukan "pengawalan" terhadap masukan-masukan mereka kepada elite daerah.

Kedua, pada tahap perencanaan, elite daerah harus menyusun naskah akademik terlebih dahulu sebagai naskah awal yang memuat gagasan-gagasan pengaturan dan pokok-pokok materi muatan bidang tertentu sebagai bahan pertimbangan yang paling objektif dan rasional dalam penyusunan Rancangan Peraturan Daerah yang ditinjau dari sisi kelayakan filosofisnya, sosiologisnya, politisnya, maupun yuridisnya. Penyusunaan naskah akademik ini tentunya didahului dengan serangkaian pengkajian dan penelitian terhadap keempat aspek tersebut. Barang tentu yang melakukan penyusunan naskah akademik tersebut tentu bukan elite daerah sendiri. Agar relatif objektif, maka penyusunan naskah akademik dilakukan oleh tenaga/staf ahli yang dimiliki elite daerah jika memang memiliki, atau jika tidak memiliki tenaga/ staf ahli maka dapat bekerja sama dengan perguruan tinggi atau lembaga lainnya yang memiliki pengalaman melakukan membuat naskah akademik untuk menjadi dasar dalam penyusunan Rancangan Peraturan Daerah. Dengan adanya naskah akademik tersebut maka dapat dijamin kerangka objektifitas tentang perlunya sebuah Peraturan Daerah diterbitkan. Dengan adanya penyusunan naskah akademik yang didasarkan pada suatu pengkajian dan penelitian, maka secara tidak langsung rencana pembentukan Peraturan Daerah telah dipublikasikan ke tengah masyarakat. Di samping itu, melalui pengkajian dan penelitian dalam rangka penyusunan naskah akademik tersebut juga secara tidak langsung masyarakat juga mulai dilibatkan untuk memberikan masukanmasukan.

Tidak terpisahkan dari kegiatan perencanaan itu adalah evaluasi Peraturan Daerah. Pada masalah ini dilakukan kajian dan pemataan untuk menentukan roadmap atau peta jalan penyusunan rencana legislasi yang akan disusun dalam kurun waktu tertentu. Untuk meningkatkan kinerja fungsi legislasi Dewan Perwakilan Rakyat Daerah, maka evaluasi produk hokum daerah, khususnya menyangkut Peraturan Daerah, menjadi penting untuk dilakukan. Tujuan pokok evaluasi ini adalah untuk melihat seberapa besar kesenjangan antara pencapaian dan harapan suatu kebijakan publik. Evaluasi produk hukum dapat dikatakan sebagai kebijakan yang tepat jika memenuhi persyaratan-persyaratan di bawah ini: 
a. Mampumenemukanhal-hal yang stra-tegis untuk meningkatkan kinerja kebijakan;

b. Pihak DPRD mampu membuat jarak dari pembuat dan pelaksana kebijakan;

c. Prosedur dapat dipertanggungjawabkan; dan

d. Dilaksanakan untuk mencapai tujuan positif.

Ketiga, agar rumusan ketentuan dalam Rancangan Peraturan Daerah memenuhi syarat formal peraturan perundang-undangan, maka elite daerah harus dibantu oleh tenaga perancang Peraturan Daerah sebagai tenaga fungsional yang berkualitas yang khusus bertugas untuk menyiapkan, mengolah, dan merumuskan Rancangan Peraturan Daerah. Barang tentu tenaga perancang Peraturan Daerah sangat diperlukan mengingat elite daerah belum tentu dapat membuat rumusan ketentuan Peraturan Daerah secara baik dan sistematis menurut kelaziman dalam penyusunan peraturan perundangundangan.

Keempat, setelah penyusunan Rancangan Peraturan Daerah selesai, maka elite daerah harus menyebarluaskan rancangan tersebut kepada publik. Penyebarluasan Rancangan Peraturan Daerah dimaksudkan untuk memperoleh tanggapan maupun usul-saran perbaikan dari publik, sehingga kekurangankekurangan yang ada dapat ditambahkan dan diperbaiki, sementara hal-hal yang tidak perlu dimasukkan kemudian dihilangkan dari Rancangan Peraturan Daerah.

Kelima, saat pembahasan di lembaga legislatif, maka elite daerah harus mengundang dan melibatkan sebanyak mungkin elemen-elemen lebih-lebih kepada stake holders (pihak yang berkepentingan dan menjadi tujuan penerbitan Perda) di luar elite daerah - yang ada di masyarakat, untuk ikut membahas dan memberi masukan dalam rangka penyempurnaan Rancangan Peraturan Daerah. Penggunaan terminologi "elemen-elemen yang ada di masyarakat" di sini dengan pertimbangan bahwa tidaklah mungkin membuat Peraturan Daerah dilakukan seperti pelaksanaan Pemilu yang melibatkan semua rakyat yang memiliki hak pilih.

Dengan demikian terdapat pembahasan yang bersifat partisipatif. Partisipasi masyarakat dalam UU No. 10 tahun 2004 tentang Pembentukan Peraturan PerundangUndangan diatur pada Bab X pasal 53

yang menyatakan bahwa masyarakat berhak memberikan masukan secara lisan atau tertulis dalam rangka penyiapan atau pembahasan rancangan undang-undang dan rancangan peraturan daerah. Penjelasan Pasal 53 itu menjelaskan bahwa hak masyarakat dalam ketentuan ini dilaksanakan sesuai dengan Peraturan Tata Tertib Dewan Perwakilan Rakyat/Dewan Perwakilan Rakyat Daerah. Senada dengan hal tersebut, dalam pasal 139 ayat (1) UU Nomor 32 Tahun 2004 Tentang Pemerintahan Daerah juga terdapat ketentuan bahwa masyarakat berhak memberikan masukan secara lisan atau tertulis dalam rangka penyiapan atau pembahasan rancangan Peraturan Daerah. Penjelasan Pasal 139 (1) tersebut menjelaskan bahwa hak masyarakat dalam ketentuan ini dilaksanakan sesuai dengan Peraturan Tata Tertib Dewan Perwakilan Rakyat Daerah.

Menarik untuk dicermati mengenai keberadaan Peraturan Tata Tertib Dewan Perwakilan Rakyat Daerah tersebut. Ketentuan UU No. 27 Tahun 2009 tentang Majelis Permusyawaratan Rakyat, Dewan Perwakilan Rakyat, Dewan Perwakilan Daerah, dan Dewan Perwakilan Rakyat Daerah Pasal 376 memerintahkan pembentukan Peraturan Tata Tertib bagi Dewan Perwakilan Rakyat Daerah Kabupaten/Kota. Prinsip-prinsip pembentukan Tata Tertib itu diatur dalam ayat (1) sampai ayat (3) sebagai berikut. pertama, pembentukan Tata Tertib dilaksanakan dengan berpedoman kepada peraturan perundang-undangan. Kedua, Tata Tertib tersebut berlaku di lingkungan internal Dewan Perwakilan Rakyat Daerah kabupaten/ kota. Ketiga, Tata Tertib Dewan Perwakilan Rakyat Daerah tersebut sekurang-kurangnya memuat aturan mengenai: (i) pengucapan sumpah/janji; (ii) penetapan pimpinan; (iii) pemberhentian dan penggantian pimpinan; (iv) jenis dan penyelenggaraan rapat; (v) pelaksanaan fungsi, tugas, dan wewenang lembaga, serta hak dan kewajiban anggota; (vi) pembentukan, susunan, serta tugas dan wewenang alat kelengkapan; (vii) pembuatan pengambilan keputusan; (viii) pelaksanaan konsultasi antara DPRD kabupaten/kota dan pemerintah daerah kabupaten/kota; (ix) penerimaan pengaduan 
dan penyaluran aspirasi masyarakat; (x) pengaturan protokoler; dan (xi) pelaksanaan tugas kelompok pakar/ahli.

Memahami adanya Peraturan Tata Tertib DPRD sesuai dengan ketentuan UU No. 27 Tahun 2009 dan merujuk kepada pengertian ini maka dapat dianalisis bahwa: (i) Peraturan Tata Tertib DPRD merupakan Peraturan Otonom sebagai bagian dari sistem perundang-undangan nasional; (ii) Sumber kewenangan pembentukan Peraturan Tata Tertib DPRD adalah undang-undang untuk melaksanakan ketentuan dalam undangundang, dalam hal ini adalah UU No. 27 Tahun 2009; (iii) Pelaksana kewenangan tersebut adalah DPRD, sebagai suatu lembaga negara; dan (iv) Kewenangan tersebut melekat terus menerus dan dapat dilaksanakan sendiri setiap waktu diperlukan, sesuai dengan batas-batas yang diberikan, yaitu batas-batas menurut ketentuan UU No. 27 Tahun 2009.

Dengan demikian, partisipasi masyarakat dalam penyusunan Peraturan Daerah merupakan hak masyarakat, yang dapat dilakukan baik dalam tahap penyiapan maupun tahap pembahasan. Dalam konteks hak asasi manusia, setiap hak pada masyarakat menimbulkan kewajiban pada pemerintah, sehingga haruslah jelas pengaturan mengenai kewajiban Pemerintahan Daerah untuk memenuhi hak atas partisipasi masyarakat dalam penyusunan Peraturan Daerah tersebut. Dari penjelasan pasal-pasal diatas dapat diketahui bahwa kewajiban tersebut ada pada Dewan Perwakilan Rakyat Daerah.

Hal ini terindikasikan dari penjelasan bahwa "hak masyarakat dalam ketentuan ini dilaksanakan sesuai dengan Peraturan Tata Tertib Dewan Perwakilan Rakyat Daerah". Berdasarkan penjelasan tersebut, partisipasi masyarakat dalam penyusunan Peraturan Daerah hanya pada tahap penyiapan dan pembahasan rancangan di Dewan Perwakilan Rakyat Daerah. Sedangkan dapat diketahui bahwa tahap penyiapan rancangan Peraturan Daerah tidak sepenuhnya dapat dilaksanakan sesuai dengan Peraturan Tata Tertib Dewan Perwakilan Rakyat Daerah. Oleh karena, penyiapan rancangan Peraturan Daerah dapat juga dilakukan oleh Kepala Daerah, lebih-lebih rancangan Peraturan Daerah tentang Anggaran Pendapatan dan Belanja
Daerah hanya berasal dari Kepala Daerah. Sehingga masih memerlukan kejelasan mengenai kewajiban untuk memenuhi hak masyarakat berpartisipasi dalam pembentukan Perda, baik pada tahap penyiapan maupun pembahasan.

Manfaat partisipasi masyarakat dalam pembuatan kebijakan publik, termasuk dalam pembuatan Perda adalah(Sad Dian Utomo 2003: 262-263), :

a. Memberikan landasan yang lebih baik untuk pembuatan kebijakan publik.;

b. Memastikan adanya implementasi yang lebih efektif karena warga mengetahui dan terlibat dalam pembuatan kebijakan publik;

c. Meningkatkan kepercayaan warga kepada eksekutif dan legislatif; dan

d. Efisiensi sumber daya, sebab dengan keterlibatan masyarakat dalam pembuatan kebijakan publik dan mengetahui kebijakan publik, maka sumber daya yang digunakan dalam sosialisasi kebijakan publik dapat dihemat.

Beberapa hal yang dapat dilakukan dalam kaitannya dengan pelaksanaan peran serta masyarakat dalam pembentukan perda antara lain: dilakukannya Rapat Dengar Pendapat Umum atau rapat-rapat lainnya yang bertujuan menyerap aspirasi masyarakat, dilakukannya kunjungan oleh anggota Dewan Perwakilan Rakyat Daerah untuk mendapat masukan dari masyarakat, ataupun diadakannya seminar-seminar atau kegiatan yang sejenis dalam rangka melakukan pengkajian atau menindak lanjuti berbagai penelitian untuk menyiapkan suatu Rancangan Peraturan Daerah. Akan tetapi dalam pelaksanaannya kadang masih terdapat berbagai penafsiran tentang siapa yang dimaksud dengan istilah masyarakat, ada yang mengartikan setiap orang pada umumnya, setiap orang atau lembaga yang terkait, atau setiap lembaga swadaya masyarakat.

Masyarakat adalah setiap orang pada umumnya terutama masyarakat yang "rentan" terhadap peraturan tersebut, setiap orang atau lembaga terkait, atau setiap lembaga swadaya masyarakat yang terkait (Maria Farida Indrati Suprapto 2007: 262-265). Mengenai sejauh mana masyarakat tersebut dapat ikut serta 
dalam pembentukan peraturan perundangundangan (dalam hal ini UU dan Perda), hal tersebut dapat tergantung pada keadaan dari pembentuk perundang-undangan sendiri oleh karena UUD dan berbagai peraturan perundang-undangan telah menetapkan lembaga mana yang dapat membentuk peraturan perundang-undangan tersebut. Apabila suatu Perda telah dapat menampung aspirasi masyarakat luas tentunya peran serta masyarakat tersebut tidak akan terlalu dipaksakan pelaksanaannya. Oleh karena itu diperlukan peningkatan kualitas anggota DPRD maupun seluruh jajaran Pemerintah yang mempunyai tugas membentuk suatu Perda.

Keenam, pada saat Rancangan Peraturan Daerah telah mendekati akhir untuk ditetapkan menjadi Peraturan Daerah, maka elite daerah hendaknya melakukan "konsultasi publik" dan "uji publik" terlebih dahulu untuk melihat reaksi masyarakat terhadap rancangan tersebut. Setidaknya ada 2 (dua) hal yang ingin dicapai dari uji publik dan konsultasi publik, yaitu (1) untuk mengetahui respons masyarakat terhadap Rancangan Peraturan Daerah yang akan ditetapkan, dan (2) untuk memperoleh persetujuan publik terhadap Raperda yang akan ditetapkan. Uji publik dan konsultasi publik terhadap Rancangan Peraturan Daerah yang akan ditetapkan tersebut bisa dilakukan dengan cara mengundang publik ke gedung Dewan Perwakilan Rakyat Daerah atupun elite daerah yang secara proaktif mendatangi elemen-elemen masyarakat daerah. Dengan agenda uji publik dan konsultasi publik tersebut elite daerah akan memiliki estimasi tentang efektif atau tidaknya Rancangan Peraturan Daerah yang akan ditetapkan tersebut dalam tahap implementasinya di masyarakat.

\section{d. Simpulan}

Berdasarkan uraian di atas dapat dikemukakan simpulan sebagai berikut:
1. Interaksi politik dalam proses pembentukan Peraturan Daerah (proses saling pengaruh mempengaruhi serta saling meminta dan memberi dan saling intervensi antara pihakpihak yang yang memiliki kekuasaan legislasi dalam proses pembentukan Peraturan Daerah) di Dewan Perwakilan Rakyat Daerah Kota Surakarta bisa saja terjadi dalam setiap tahap proses pembentukan Peraturan Daerah - Namun interaksi politik dalam proses pembentukan Perda ini secara intensif terjadi pada tahap pembahasan Rancangan Peraturan Daerah, khususnya terjadi pada saat rapat kerja antara Panitia Khusus Dewan dengan Perangkat Daerah.

2. Konsep ideal legislasi Peraturan Daerah ke depan adalah berdasarkan demokrasi elitis-populis, yang mana antara elite daerah dan populus/demos harus bekerja sama secara kekeluargaan, kegotongroyongan, dan dengan penuh semangat kebersamaan dalam bingkai harmoni, sehingga dari sistem politik demikian ini akan dapat dihasilkan produk Perda yang sesuai dengan kebutuhan daerah dan mengakomodasikan sebanyak mungkin kepentingan dan aspirasi masyarakat.

\section{E. Saran}

berikut:

Dari penelitian ini disarankan sebagai

1. Konsepsi interaksi politik demokrasi Indonesia dalam kaitannya dengan legislasi harus diberi makna baru, yakni menjalinkan demokrasi yang nilai dasarnya adalah harmoni yang tidak mengutamakan kepentingan individu dan kelompok maupun juga tidak menegasikan kepentingan individu dan kelompok dengan kedaulatan rakyat serta partisipasi warga negara secara berkelanjutan sebagai prinsip dasar demokrasi.

2. Perlu ada ketentuan baru yang mengatur secara umum mengenai siapa yang dilibatkan dalam legislasi Peraturan Daerah. 


\section{daftar Pustaka}

A. Hamid S. Attamimi. 1990. peranan Keputusan presiden republik Indonesia dalam penyelenggaraan Pemerintahan Negara (Suatu Studi Analisis mengenai Keputusan Presiden yang Berfungsi Pengaturan dalam Kurun Waktu PELITA I - PELITA IV). Disertasi Doktor IImu Hukum, Fakultas Pascasarjana UI, Jakarta.

B. Bastian Tafal. 1992. pokok-pokok Tata Hukum di Indonesia. Jakarta: Penerbit Gramedia Pustaka Utama.

Daniel S. Lev. "Sejarah Penggunaan Hukum di Indonesia”. Jentera Jurnal Hukum. Edisi 3-Tahun II, November 2004.

F.X. Adji Samekto. 2003. Studi Hukum Kritis, Kritik Terhadap Hukum Modern, Semarang: Badan Penerbit Universitas Diponegoro.

Franz-Magnis Suseno. 1999. Etika politik. Jakarta: Gramedia Pustaka Utama.

H.R. Ridwan. 2004. Hukum Administrasi Negara. Jogjakarta: Penerbit UII Press.

Imam Syaukani dan A. Ahsin Tohari. 2007. Dasar-Dasar politik Hukum. Jakarta: Penerbit Rajawali.

Koentjaraningrat. 1997. Metode-Metode penelitian Masyarakat. Jakarta: Penerbit Gramedia Pustaka Utama.

Moh. Mahfud M.D.. 1998. politik Hukum di Indonesia, Jakarta, Penerbit LP3ES.

M. Solly Lubis, 1989, Serba-Serbi politik dan Hukum. Bandung: Penerbit Mandar Maju.

Padmo Wahyono. 1986. Indonesia Negara Berdasarkan Hukum. Jakarta: Penerbit Ghalia Indonesia.

Ronny Hanitiyo Soemitro. 1985. Studi Hukum dan Masyarakat. Bandung: Penerbit Alumni.

Satjipto Rahardjo. 1980. Hukum, Masyarakat, dan pembangunan. Bandung: Penerbit Alumni. 1996. Ilmu Hukum. Bandung: Penerbit Citra Aditya Bakti. 2003. Sisi-Sisi Lain Hukum di Indonesia. Jakarta: Penerbit Buku Kompas.

Soedarto. 1986. Hukum dan Hukum pidana. Bandung: Penerbit Alumni.

Teuku Mohammad Radhie, "Pembaharuan dan Politik Hukum dalam Rangka Pembangunan Nasional", Jurnal prisma, No. 6 Tahun II, Desember 1973. 